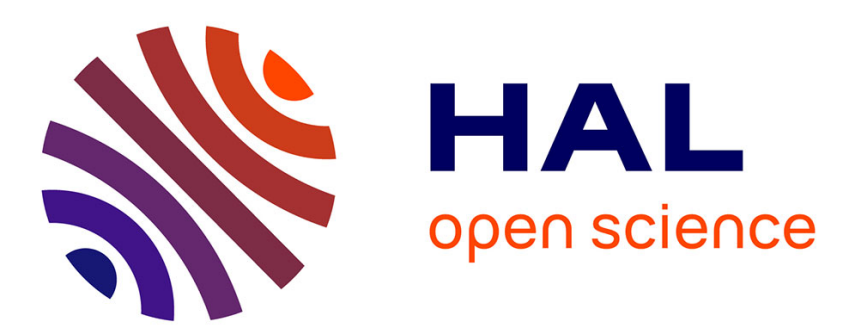

\title{
Development of oxidation resistant high temperature NbTiAl alloys and intermetallics
}

\author{
Michel Allouard, Yves Bienvenu, Loic Nazé, Cora Bracho-Troconis
}

\section{To cite this version:}

Michel Allouard, Yves Bienvenu, Loic Nazé, Cora Bracho-Troconis. Development of oxidation resistant high temperature NbTiAl alloys and intermetallics. Journal de Physique IV Proceedings, 1993, 03 (C9), pp.C9-419-C9-428. 10.1051/jp4:1993944 . jpa-00252384

\section{HAL Id: jpa-00252384 https://hal.science/jpa-00252384}

Submitted on 1 Jan 1993

HAL is a multi-disciplinary open access archive for the deposit and dissemination of scientific research documents, whether they are published or not. The documents may come from teaching and research institutions in France or abroad, or from public or private research centers.
L'archive ouverte pluridisciplinaire HAL, est destinée au dépôt et à la diffusion de documents scientifiques de niveau recherche, publiés ou non, émanant des établissements d'enseignement et de recherche français ou étrangers, des laboratoires publics ou privés. 


\title{
Development of oxidation resistant high temperature NbTiAl alloys and intermetallics
}

\author{
M. Allouard, Y. Bienvenu, L. Nazé and C.B. Bracho-Troconis
}

Ecole des Mines de Paris, Centre des Matériaux P.M. Fourt, BP. 87, 91003 Evry Cedex, France

\begin{abstract}
The effect of alloying elements like Ti, $\mathrm{Al}, \mathrm{Cr}, \mathrm{V}$ and $\mathrm{Mo}$ on the oxidation resistance of $\mathrm{Nb}$ at high temperature (between $700^{\circ} \mathrm{C}$ and $1400^{\circ} \mathrm{C}$ ) has been studied. The value of the parabolic oxide growth constants, $0.1 \mathrm{~g}^{2} / \mathrm{cm}^{4} \mathrm{~s}<K_{\mathrm{p}}<100 \mathrm{~g}^{2} / \mathrm{cm}^{4} \mathrm{~s}$, depends on the nature and morphology of oxides formed in the external scale. The growth of protective oxides, like alumina, requires a high content of alloying elements, which usually means a lower melting point and the formation of brittle phases.
\end{abstract}

\section{Introduction.}

The improvement of aircraft engines efficiency requires the increase of service temperature of various components. The maximum temperature-stress limit combination of nickel base superalloys has almost been reached and an increase of several hundreds degrees of the temperature requires the use of new alloys [1].

New refractory metals are being considered for advanced gas turbine engine applications. Among them, niobium, with its high melting point and moderate density shows a good potential as a base for new aerospace alloys. However, the mechanical properties at high temperature of current commercial $\mathrm{Nb}$ alloys are too low and the oxidation resistance has to be improved by adding significant amounts of Ti and Al. Such alloy compositions lead to the formation of ordered intermetallic phases [2].

The strengthening of $\mathrm{Nb}$ alloys based on solid solution and on carbide precipitation is detrimental to density and unsufficient. Strengthening by thermodynamically stable and not too brittle intermetallic phases is considered. It requires the study of the nature and structure of the phases in equilibrium and of the transformation temperatures.

The first approach to improve the oxidation resistance of $\mathrm{Nb}$ alloys consisted in alloying with elements such as $\mathrm{Ti}, \mathrm{Cr}, \mathrm{V}, \mathrm{Mo}, \mathrm{Al}$ in order to dope the $\mathrm{Nb}_{2} \mathrm{O}_{5}$ oxide or to modify its fracture behaviour. This was not sufficient and it appeared that alloying in order to produce a more resistant surface oxide was required [3]. The second approach was to allow the formation of more protective oxides such as $\mathrm{AlNbO}_{4}$ or $\mathrm{Al}_{2} \mathrm{O}_{3}$. The literature [4] based on the Wagner approach suggests that the critical $\mathrm{Al}$ content $\left(N_{\mathrm{Al}}\right)_{\text {crit }}$ necessary to form an external alumina scale is related to the oxygen solubility $\left(N_{O}\right)$, and to the oxygen and aluminium diffusivities $\left(D_{\mathrm{O}}, D_{\mathrm{Al}}\right)$ in $\mathrm{Nb}$-Al. In binary alloys this value is very high and the alloy has to incorporate some elements to reduce $N_{\mathrm{O}}$ and $D_{\mathrm{O}}$ and to increase $D_{\mathrm{Al}}$ and thus decrease $\left(N_{\mathrm{Al}}\right)_{\text {crit }}$. 
The object of this paper is the description of the oxidation behaviour and the effect of some alloying elements like $\mathrm{Ti}, \mathrm{Al}, \mathrm{Cr}, \mathrm{Mo}$ and $\mathrm{V}$ to improve the oxidation resistance of some $\mathrm{Nb}$ ternary alloys at high temperature.

\section{Experimental.}

The alloys were prepared at ONERA by tungsten-arc melting under an argon atmosphere to form $80 \mathrm{~g}$ buttons. They were heat treated or extruded at temperatures up to $1300^{\circ} \mathrm{C}$.

The phase characterisation was made by $\mathrm{X}$-ray diffraction, electron microprobe analysis (EPMA) and by transmission electron microscopy (TEM). Some transition temperatures were determined by differential thermal analysis (DTA).

The mass increase upon oxidation as a function of time was measured by thermogravimetry between $700^{\circ} \mathrm{C}$ and $1400^{\circ} \mathrm{C}$ in both air and oxygen, with exposure times up to $100 \mathrm{~h}$. Finally, oxidized samples were evaluated by metallography and other techniques mentionned above.

\section{Results and discussion.}

3.1 THE MICROSTRUCTURE. - A number of ternary alloys, shown in figure 1 [5], has been produced to study the different phases. This paper describes in more details the performance of A, B, C and D alloys (compositions listed in Tab. I). The zirconium content, usual in $\mathrm{Nb}$ alloys, lowers the dissolved oxygen contamination forming small internal particles of $\mathrm{ZrO}_{2}$ oxide.

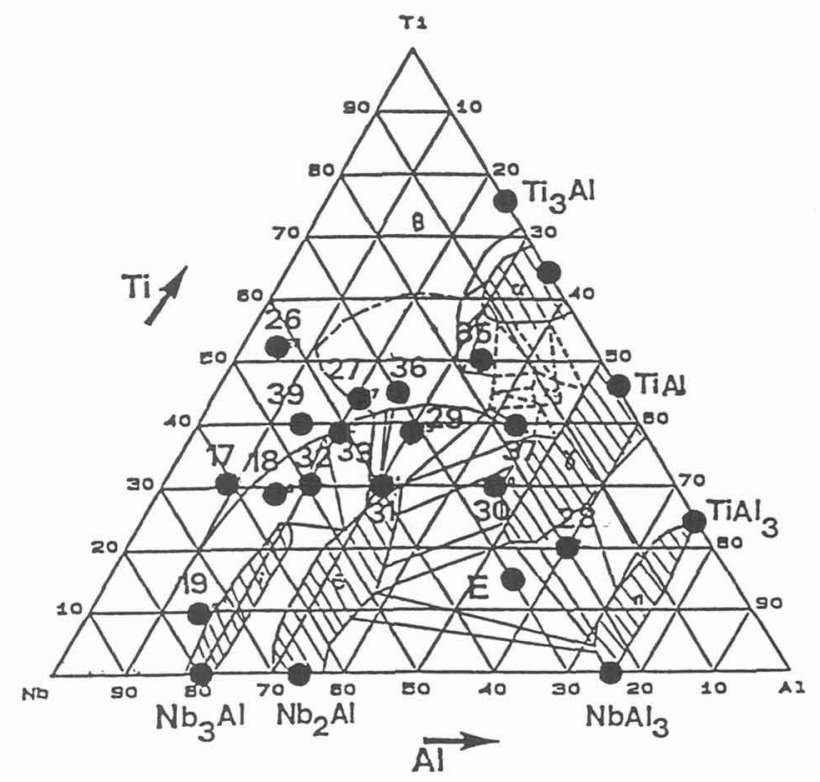

Fig. 1. - NbTiAl ternary phase diagram [5] at $1200^{\circ} \mathrm{C}$ with the alloys studied. 
Table I. - Alloys composition (in atomic per cent).

\begin{tabular}{|c|c|c|c|c|c|c|}
\hline & NB & Ti & Al & V & Cr & Zx \\
\hline NB 28 & 19,8 & 19,8 & 59,4 & & & 1,0 \\
\hline NB 29 & 31,2 & 38,1 & 29,70 & & & 1,0 \\
\hline NB 30 & 24,7 & 29,7 & 44,5 & & & 1,0 \\
\hline NB 31 & 39,6 & 29,7 & 29,7 & & & 1,0 \\
\hline NB 32 & 49,5 & 29,7 & 19,8 & & & 1,0 \\
\hline NB 33 & 41,1 & 38,1 & 19,8 & & & 1,0 \\
\hline NB 34 & 54,0 & 30,0 & 15,0 & & & 1,0 \\
\hline NB 35 & 16,5 & 50,0 & 32,5 & & & 1,0 \\
\hline NB 36 & 30,0 & 46,5 & 22,5 & & & 1,0 \\
\hline NB 37 & 16,5 & 40,0 & 42,5 & & & 1,0 \\
\hline NB 38 & 15,5 & 36,5 & 40,0 & 4,0 & 3,0 & 1,0 \\
\hline NB 39 & 44,5 & 40,0 & 14,5 & & & 1,0 \\
\hline
\end{tabular}

Aluminium solubility (between $10 \%$ and more than $30 \%$ atom.) in bcc $\mathrm{Nb}$ is strongly influenced by the Ti content (increases with increasing $\mathrm{Ti}$ ). For the low $\mathrm{Al}$ contents, the $\delta-\mathrm{Nb}_{3} \mathrm{Al}$ phase is present in the alloys; this phase is stable and hard at high temperature. However, this alloy shows a low oxidation resistance.

When the aluminium content increases, $\sigma-\mathrm{Nb}_{2} \mathrm{Al}$ precipitates in the ordered $\mathrm{B} 2$ matrix, alloy $\mathrm{A}$ (Fig. 2), or in a $\mathrm{Ll}_{0} \gamma$-TiAl matrix, alloy $\mathrm{B}$ (Fig. 3).

This $\mathrm{Nb}_{2} \mathrm{Al}$ phase which can dissolve more than $30 \%$ at. of $\mathrm{Ti}$ is observed in most of the alloys studied and is detrimental to ductility. The DTA results on A and B alloys, show that $\sigma-\mathrm{Nb}_{2} \mathrm{Al}$ is stable up to $1260^{\circ} \mathrm{C}$ in $\mathrm{B} 2$ (Alloy A) and up to $1330^{\circ} \mathrm{C}$ in $\gamma$-TiAl (Alloy B) where an eutectoid reaction occurs: $\mathrm{TiAl}+\mathrm{Nb}_{2} \mathrm{Al} \rightarrow \mathrm{B} 2$ (see Figs. 2 and 3). This transition provides a good oxidation behaviour (as shown below) because the aluminium diffusivity is higher in the $\mathrm{B} 2$ structure than in the two phase $\gamma$-TiAl $-\sigma-\mathrm{Nb}_{2} \mathrm{Al}$ alloy [4].

In order to improve the ductility, other alloys were studied with high titanium content to avoid $\sigma-\mathrm{Nb}_{2} \mathrm{Al}$ or $\eta-\mathrm{NbAl}_{3}$ brittle phase precipitation. Nevertheless, for the high $\mathrm{Ti}$ and $\mathrm{Al}$ contents the $\mathrm{B} 2$ phase is not stable. For example, alloy $\mathrm{C}$ (after heat treatment at $1200^{\circ} \mathrm{C}$ ), figure 4, contains two different microstructural scales. The coarse scale refers to the microstructure present in the high temperature structure $\left(\mathrm{B} 2+\alpha_{2}-\mathrm{Ti}_{3} \mathrm{Al}\right)$, while on a finer scale we observe a phase transformation of the B2 matrix during cooling, into an omega related phase. This result is in agreement with those of Bendersky et al. [6]. Additional studies are necessary to understand the heat treatment sensitive microstructure existing in this part of the ternary diagram. 
a)

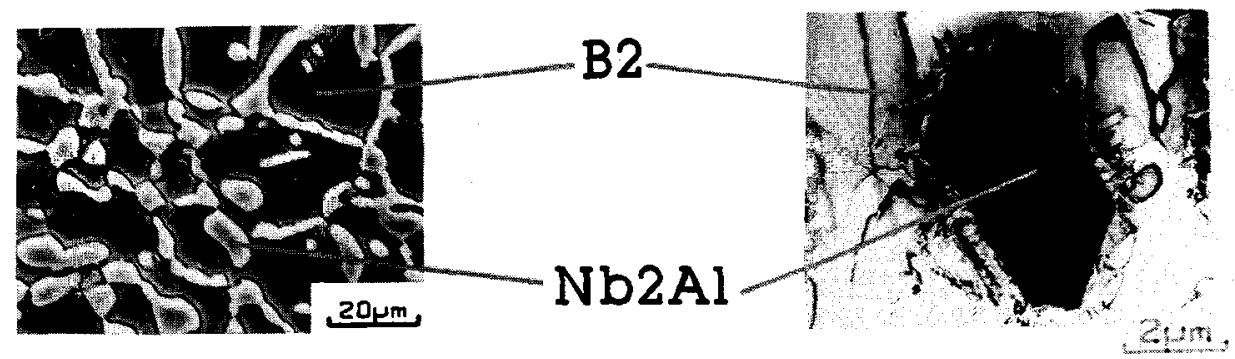

extruded alloy

extruded alloy M.E.T. $(300 \mathrm{kV})$

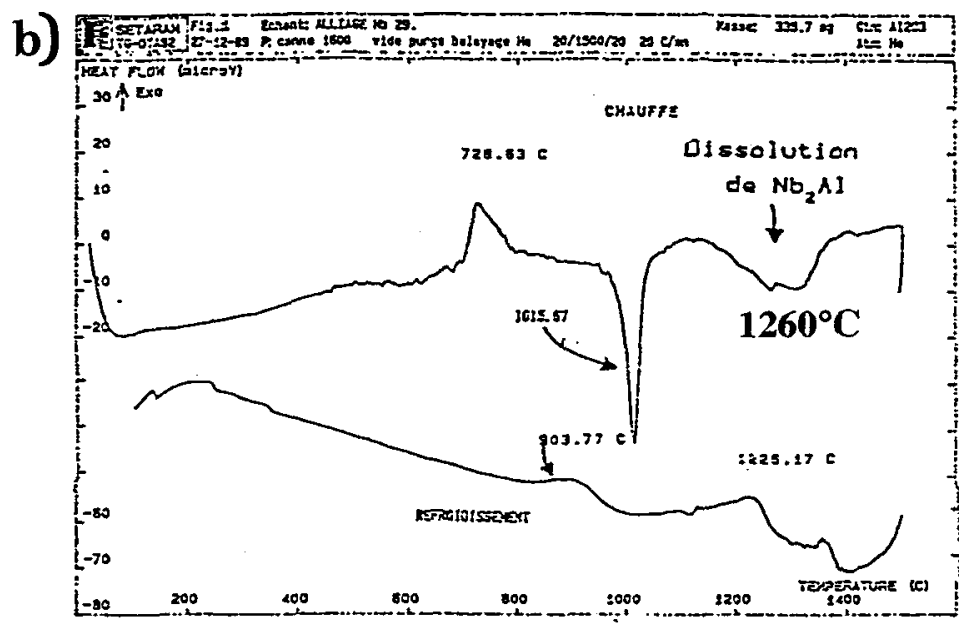

\section{$1260^{\circ} \mathrm{C}$ $\mathrm{B} 2+\mathrm{Nb} 2 \mathrm{Al} \rightarrow \mathrm{B} 2$}

Fig. 2. - a) Microstructure of A alloy. b) Stability of $\mathrm{Nb}_{2} \mathrm{Al}$ in $\mathrm{B} 2$ matrix (DTA, $20^{\circ} \mathrm{C} / \mathrm{min}$ ).

3.2 OXIDATION BEHAVIOUR. - Study of the oxidation behaviour has permitted to demonstrate the effect of alloying elements like $\mathrm{Ti}, \mathrm{Al}, \mathrm{Cr}, \mathrm{V}$ and $\mathrm{Mo}$ to improve oxidation resistance at high temperature. On the one hand, we have studied different alloys which had a constant $\mathrm{Ti}$ content or a constant $\mathrm{Al}$ content or $\mathrm{Nb} / \mathrm{Ti}$ ratios equal to 0.8 . On the other hand, we have studied some intermetallics (Fig. 5).

Figure 5 shows the effect of aluminium additions on the oxidation resistance of alloys. The value of $K_{\mathrm{p}}$ (parabolic oxide growth constant) measured on a time basis up to $100 \mathrm{~h}$, depends on the nature of the oxides formed in the external scale. With $10 \%$ of $\mathrm{Al}$, the main oxide is $\mathrm{TiNb}_{2} \mathrm{O}_{7}$. With $20 \%$ of $\mathrm{Al}$, a small quantity of $\mathrm{AlNbO}_{4}$ appears. With $30 \%$ of $\mathrm{Al}$, $\mathrm{AlNbO}_{4}$ becomes the main oxide. With $44 \%$ of Al (Alloy B) the scale morphology (Fig. 6) shows the competition between $\mathrm{Al}_{2} \mathrm{O}_{3}, \mathrm{TiO}_{2}$ and $\mathrm{AlNbO}_{4}$. At $1200{ }^{\circ} \mathrm{C}$, the diffusivity of $\mathrm{Al}$ is not sufficient to allow the formation of a continuous scale of alumina. We can see the precipitation of a subscale of $\mathrm{Nb}_{2} \mathrm{Al}$, resulting from the depletion of $\mathrm{Al}$ near the metal-oxide interface, due to a low $\mathrm{Al}$ diffusivity. In the case of oxidation at $1400^{\circ} \mathrm{C}$ in air, no depletion is observed, and the diffusivity is sufficient to allow the formation of a protective alumina scale.

The addition of a low titanium content (Fig. 7) permits the formation of more protective oxides in the outer scale such as $\mathrm{TiNb}_{2} \mathrm{O}_{7}$ or $\mathrm{TiO}_{2}$. High contents of $\mathrm{Ti}$ increase the aluminium solubility in Nb. Furthermore, with high Al content it stabilizes the B2 phase where 
a)
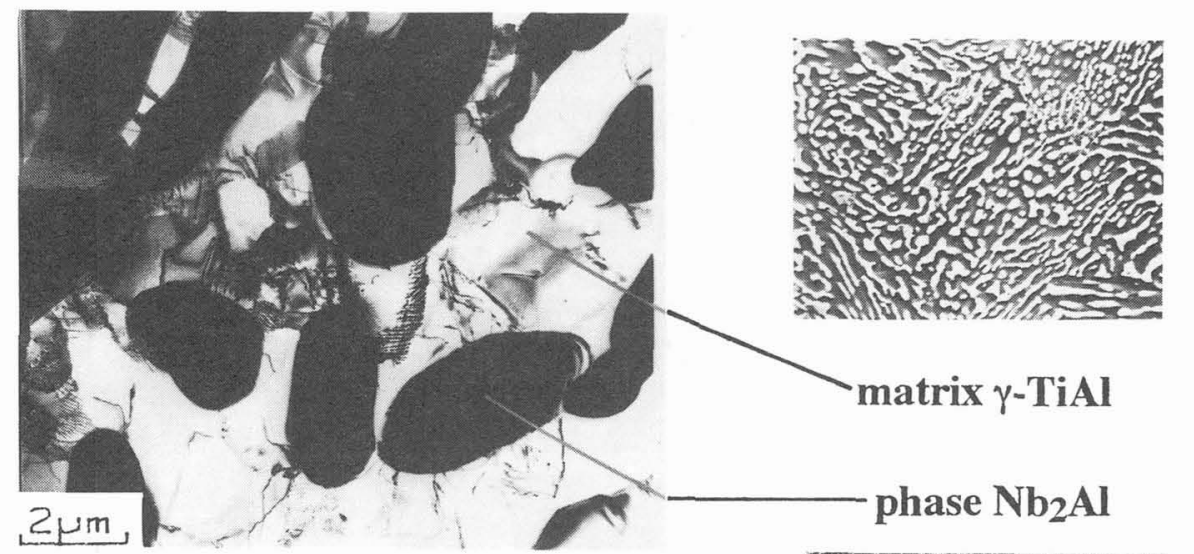

$100 \mu \mathrm{m}$

After heat $\mathrm{T} .=1200^{\circ} \mathrm{C}$

(M.E.T. 300kV)

b)
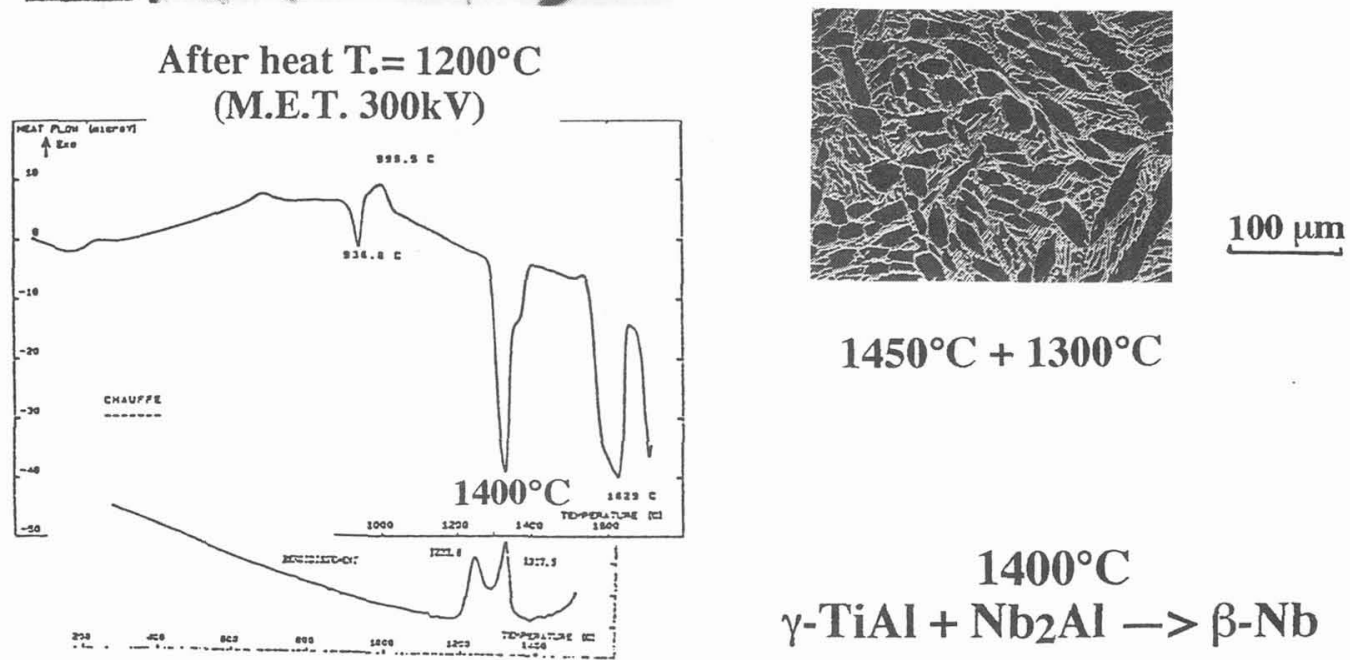

$1450^{\circ} \mathrm{C}+1300^{\circ} \mathrm{C}$

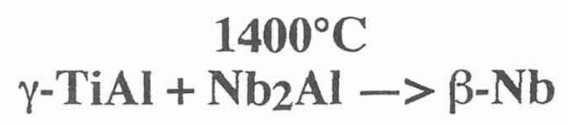

Fig. 3. - a) Microstructure of $\mathrm{B}$ alloy. b) Stability of $\mathrm{Nb}_{2} \mathrm{Al}$ in $\gamma$-TiAl matrix (DTA, $20^{\circ} \mathrm{C} / \mathrm{min}$ ).

$\mathrm{Al}$ diffusivity is high. With high aluminium contents at $1000^{\circ} \mathrm{C}$, the increase of $\mathrm{Ti}$ improves the oxidation resistance but at $1400^{\circ} \mathrm{C}$ an increase of $10 \%$ prevents the formation of alumina on $\mathrm{NbTiAl}$ alloy containing about $43 \%$ of $\mathrm{Al}$ and favours the growth of other oxides.

The effect of $\mathrm{Cr}$ and $\mathrm{V}$ depends strongly on oxidation temperature (Fig. 8). At lower temperatures $\left(1000^{\circ} \mathrm{C}\right)$, the addition of low $\mathrm{Cr}$ and $\mathrm{V}$ content increases the oxidation rate. At $1200^{\circ} \mathrm{C}$, there is no clear effect, but at high temperatures, such addition produces a decrease of $K_{\mathrm{p}}$ of two orders of magnitude. As discussed above, these elements decrease oxygen diffusivity and solubility in the alloy and enhance the formation of the alumina scale.

Therefore, the addition of low $\mathrm{Cr}$ and $\mathrm{V}$ contents and high Ti content leads to continuous alumina scale formation for alloy D, (Fig. 9) which does not contain the two brittle phases $\left(\mathrm{Nb}_{2} \mathrm{Al}\right.$ or $\left.\mathrm{NbAl}_{3}\right)$ in opposition with alloy $\mathrm{B}$ and with the majority of the alloys studied in the literature.

Other elements are being considered for alloying such as Mo but evaporation of $\mathrm{MoO}_{3}$ oxides was observed above $800^{\circ} \mathrm{C}$. 


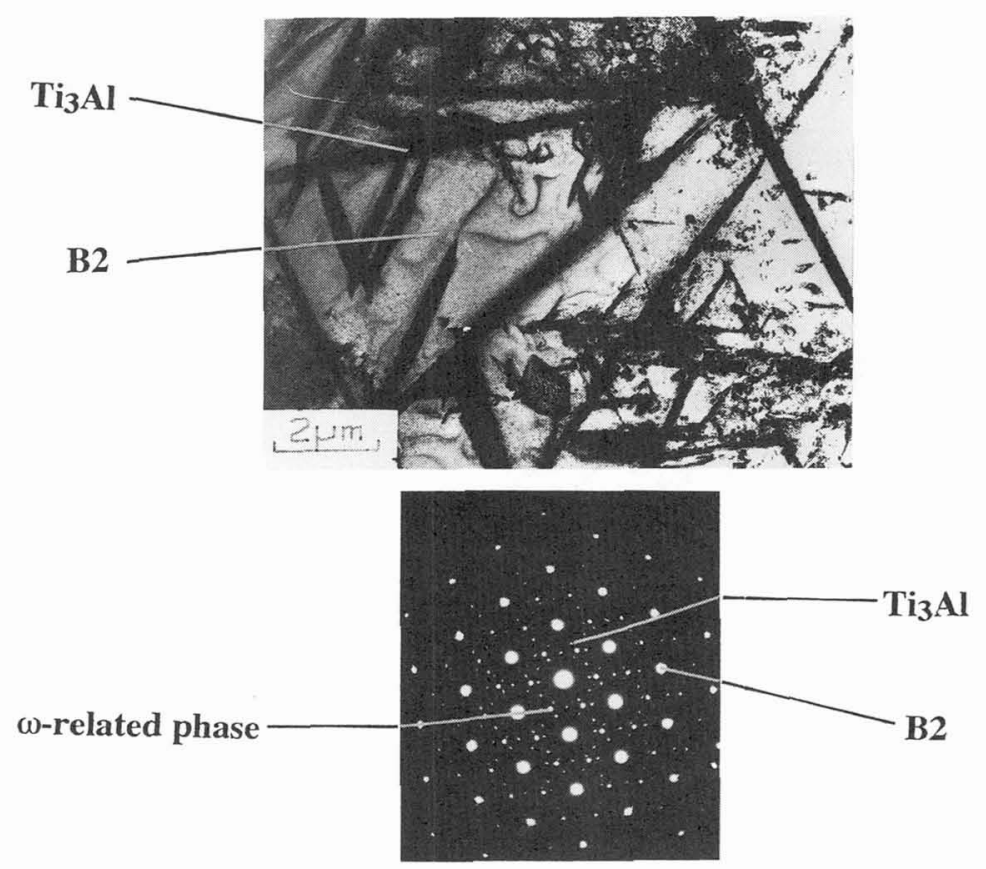

Fig. 4. - Microstructure of $\mathrm{C}$ alloy.

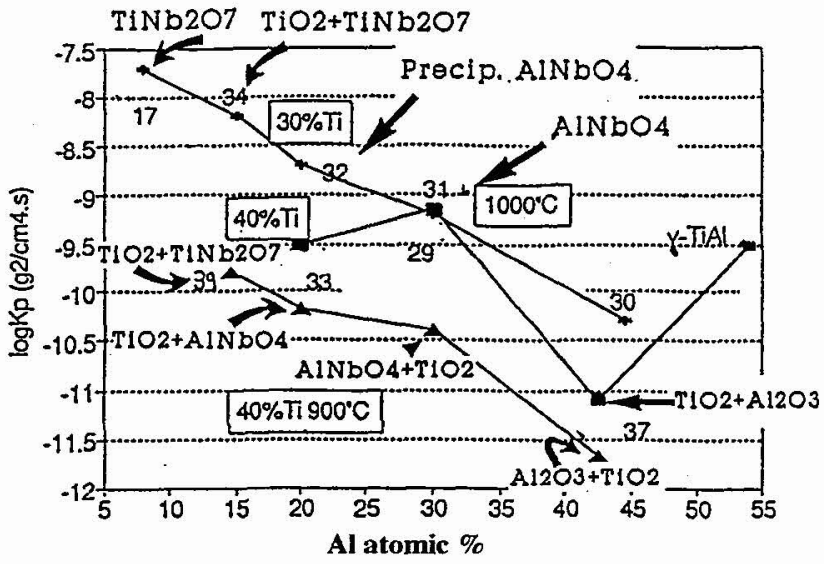

Fig. 5. - Influence of the $\% \mathrm{Al}$ on the parabolic rate constant. $\mathrm{Nb}-30,40 \% \mathrm{Ti}$ at 900 and $1000^{\circ} \mathrm{C}$ in air.

To summarize, we may distinguish 3 domains in the field of experimental variables investigated here (temperature and $\mathrm{Al}$ content): i) the first one, where the Al content is smaller than $\left(N_{\mathrm{Al}}\right)_{\text {crit }}$ (critical Al content), the main oxide being $\mathrm{Nb}_{2} \mathrm{O}_{5}$; ii) the second where the $\mathrm{Al}$ content is high enough to form an alumina scale but where Al diffusivity in the metal is smaller than in the oxide leading to the formation of other oxides; iii) the third where Al content is greater than $\left(N_{\mathrm{Al}}\right)_{\text {crit }}$ and the diffusivity in the metal is greater than in the oxide allowing the formation of a continuous alumina scale. Figures 10 summarizes the different oxides found 


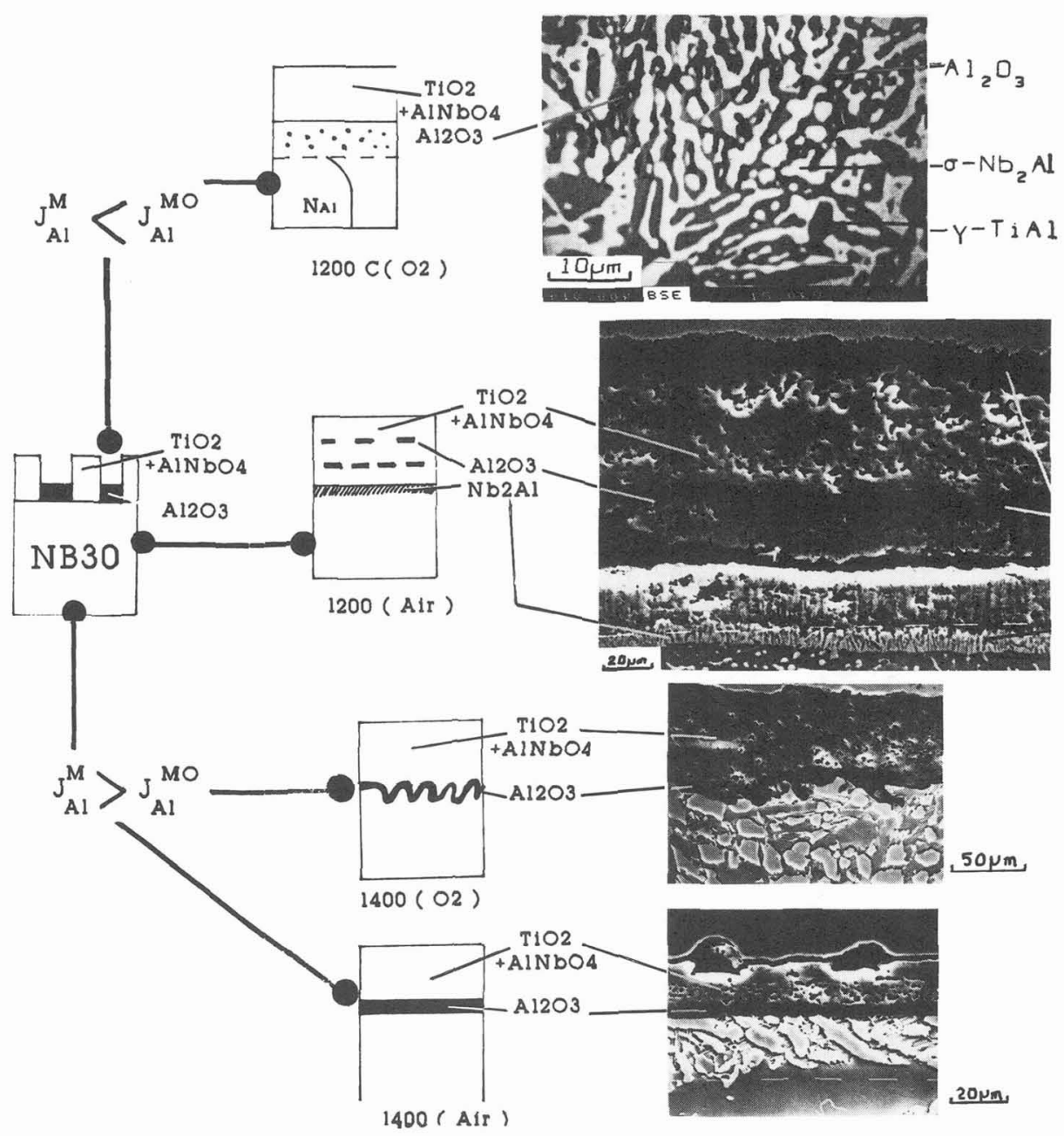

Fig. 6. - Formation of a protective alumina scale on alloy B.

in our ternary alloys. $\mathrm{Al}_{2} \mathrm{O}_{3}$ is only present in $\mathrm{B}$ and $\mathrm{D}$ alloys with $\mathrm{Al}$ contents of 45 and $40 \%$ respectively.

Finally, the effects of oxygen partial pressures and nitrogen environment have been studied. For alloys with high Ti content, binary TiAl intermetallics and Ti rich NbTiAl alloys with low contents in other alloying elements, the oxidation rate is higher in air than in oxygen, showing a nitrogen effect.

On the one hand, for alloys with high $\mathrm{Al}$ content, the increase in $P_{\mathrm{O}_{2}}$ produces an increase in oxidation rates at low temperature. At such temperature, internal oxidation, specially of $\mathrm{Al}$, is important. On the other hand, at high temperature, the effect is weak and in the case of alloy $\mathrm{D}$, the temperature required for the transition from internal to external oxidation was lower. 

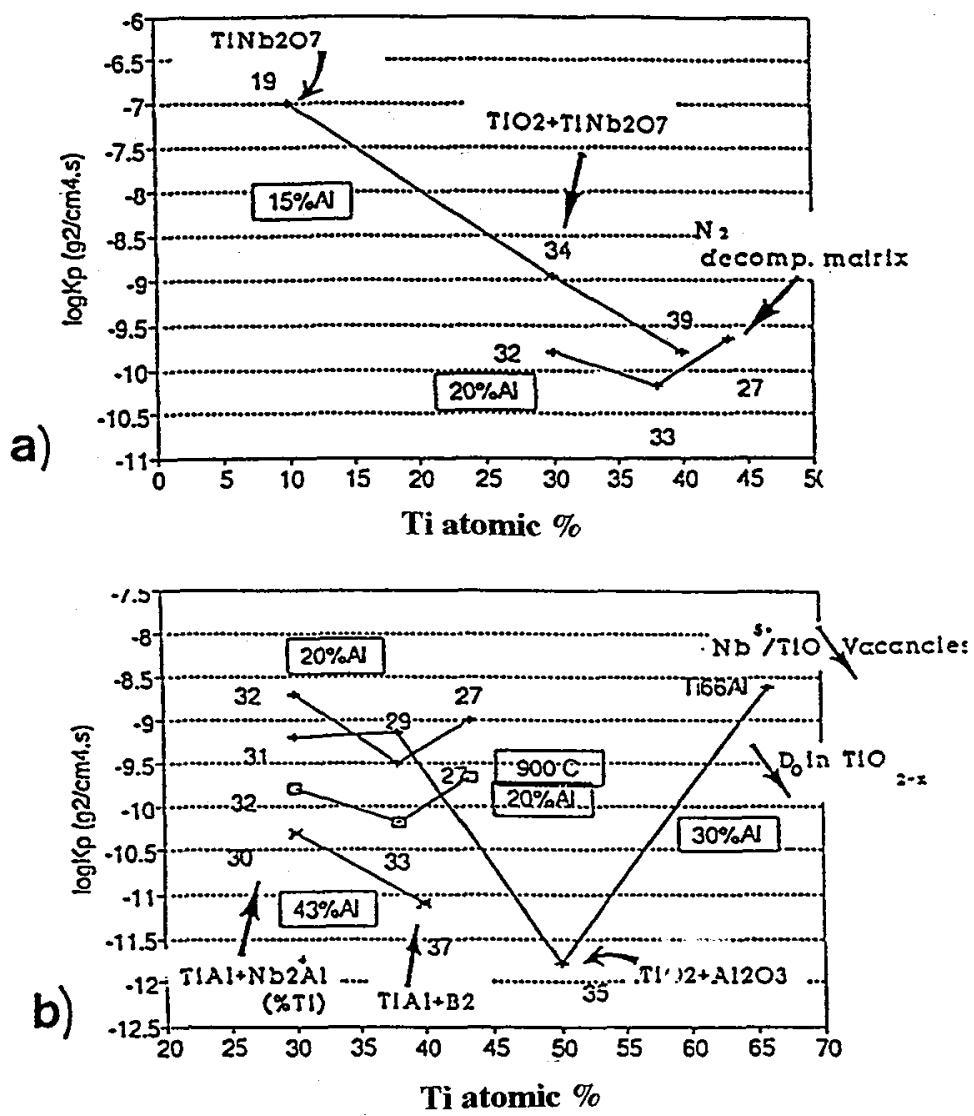

Fig. 7. - Influence of the $\% \mathrm{Ti}$ on the parabolic rate constant: a) $\mathrm{Nb}-15,20 \% \mathrm{Al}$ at $900{ }^{\circ} \mathrm{C}$ in air; b) $\mathrm{Nb}-20,30,43 \% \mathrm{Al}$ at $1000^{\circ} \mathrm{C}$ in air.

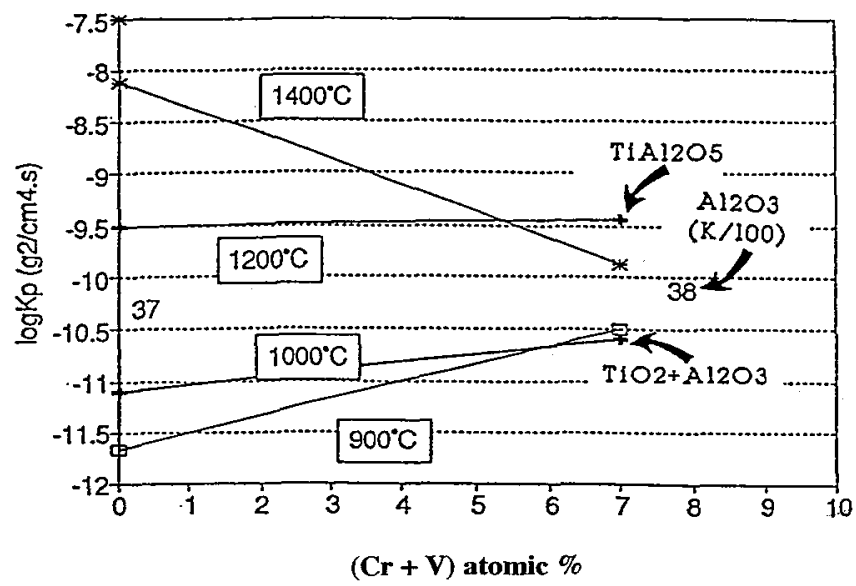

Fig. 8. - Influence of the $\%(\mathrm{Cr}-\mathrm{V})$ on the parabolic rate constant $\mathrm{Nb}-40 \% \mathrm{Ti}-42 \% \mathrm{Al}$ at $1000{ }^{\circ} \mathrm{C}$ in air. 
$1400^{\circ} \mathrm{C}$ AIR

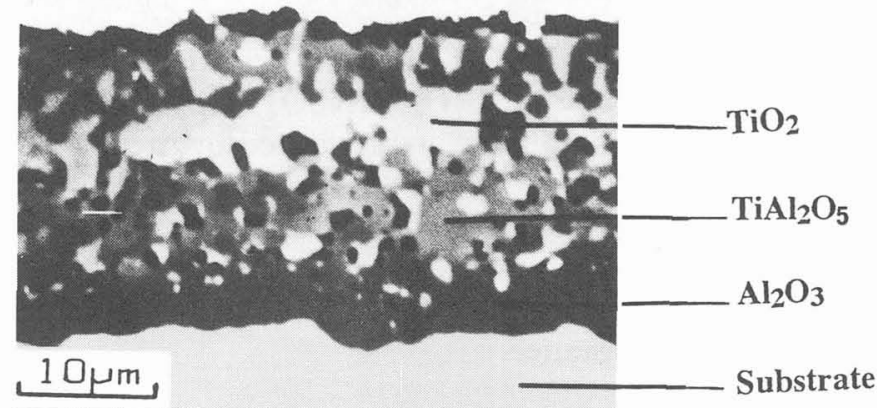

$1350^{\circ} \mathrm{C} \mathrm{AIR}$

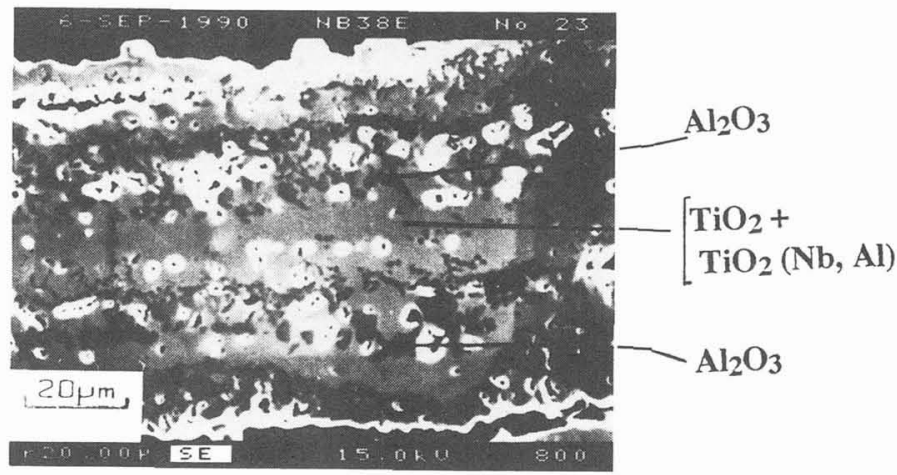

Fig. 9. - Morphology of the oxide scale on alloy D.

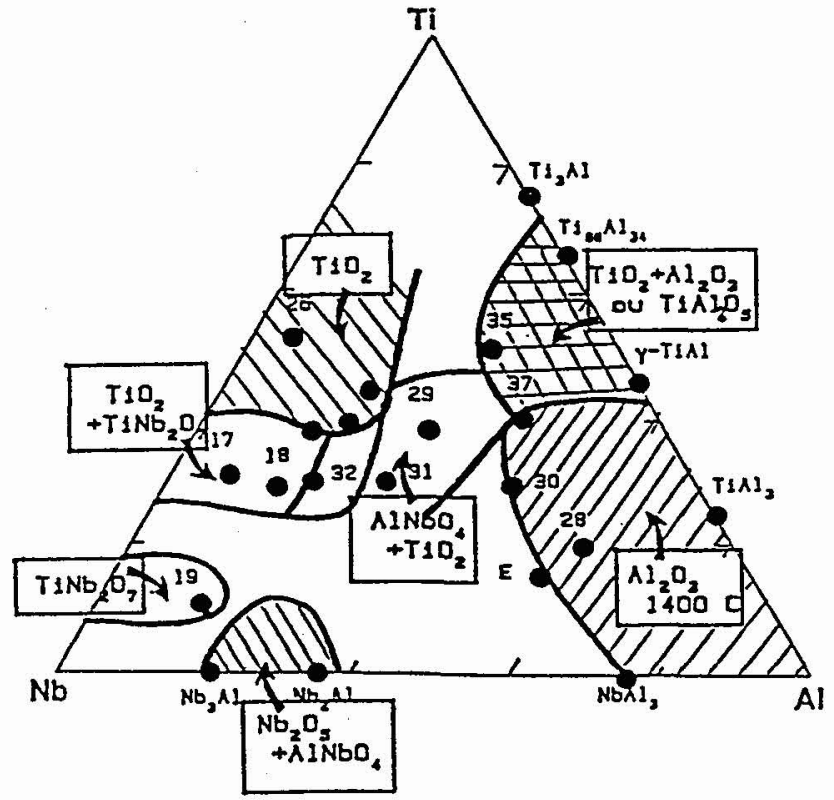

Fig. 10. - Oxide map of $\mathrm{NbTiAl}$ alloys at high temperature. 


\section{Conclusion.}

The parabolic rate constants, $K_{\mathrm{p}}$, depend on the nature and morphology of oxides formed in the external scale, principally $\mathrm{TiNb}_{2} \mathrm{O}_{7}, \mathrm{AlNbO}_{4}, \mathrm{TiO}_{2}$ and $\mathrm{Al}_{2} \mathrm{O}_{3}$ (ranked in the order of increasing oxidation resistance). They are governed by the alloy composition and by diffusivities.

The formation of protective oxides requires a high content of alloying elements (Al, $\mathrm{Ti}$ ), which may lower the melting point and lead to the formation of brittle phases. We are going to consider next the effect of powder metallurgy manufacturing on microstructure, mechanical properties and oxidation resistance.

\section{Acknowledgements.}

This work was supported by the "Direction des Recherches Etudes et Techniques" and by SNECMA. We acknowledge the contribution of ONERA in the manufacturing of test samples and in the design of new alloys.

\section{References}

[1] HONNORAT Y., Considerations sur les règles de choix des matériaux pour hautes températures dans les moteurs aéronautiques modernes, Entretiens Science et Défense 90, Dunod Ed. (1990).

[2] LORIA E.A., J. Met. 7 (1987) 22-26.

[3] Perkins R.A., MEIER G.H., J. Met. 8 (1990) 17-21.

[4] Perkins R.A., Ghiang K.T., Meier G.H., Scr. Metall. 22 (1988) 419-424.

[5] Perepezko J.H., Chang Y.A., Seitzman L.E., Lin J.C., Bonda N.R., JewetT T.J., MISHURDA J.C., High temperature phase stability in the TiAlNb system, High temperature aluminides and intermetallics, S.H. Wang, C.T. Liu, D.P. Pope, J.O., Stiegler Eds. (The Minerals Metals and Materials Society, 1990).

[6] Bendersky L.A., BoetTinger W.J., Burton B.P., Biancaniello F.S., ShoemakeR C.B., Acta Metall. Mater. 38 (1990) 931-943. 